\title{
THE HUMIDIFICATION OF ANAESTHETIC GASES: ITS IMPORTANCE AND CONTROL
}

\author{
Jack Chalun, Mahgul Ali, Sivam Ramanathan and Herman Turndorf
}

\section{Purpose. Definitions and Regulation}

THIS REVIEW studies the humidity output of anaesthetic systems in common use and the steps taken to improve them. The amount of water vapour which an atmosphere can hold varies with temperature. The warmer the ambient gas mix. ture, the more water vapour it can contain. There is a maximum amount of water vapour which the atmosphere can maintain at each temperature when it becomes saturated. Saturated humidity can be expressed as: (1) 100 per cent moisture at a given temperature, (2) the amount of water weight for volume held by the gas $\left(\mathrm{mg} \mathrm{H}_{2} \mathrm{O} / \mathrm{lor} \mathrm{g}\right.$ $\left.\mathrm{H}_{2} \mathrm{O} / \mathrm{m}^{3}\right)$, or (3) the partial pressure exerted by the water vapour in millimeters of mercury (torr), or S.I. units as kilo-Pascals (one $\mathrm{kPa}=7.5$ torr). Relutive humidity is the per cent saturation of the atmosphere at a given temperature. It can be expressed as such or in absolute values (amount of water in gas as weight for volume or as pressure of water vapour).

Water vapour enters the atmosphere by emerging from a water supply or by sublimation of ice. The amount of vapour which is formed depends on the temperature of the water because vapour pressure rises with temperature. As vaporization proceeds, the water cools to provide the energy required for transformation into vapour. The emission of vapour is reduced as the source of water cools unless heat is available to provide the energy for transformation (latent heat of vaporization).

If a gas saturated with water vapour is cooled either by a drop in ambient temperature or by passage through a condenser, it will rain out the amount of water vapour it held at the original temperature less the amount it can now hold at

Jack Chalon, M.D., Professor and Associate Director: Muhgul Ali, M.D., Assistant Professor; Sivam Ramanathan, M.D. Assistant Professor; Herman Turndorf, M.D. . Professor and Chairman; Department of Anesthesiology, New York University Medical Center, 550 First Avenue. New York. N.Y. 10016. U.S.A.

Reprint requesis to: J. Chalon, M.D., 9 Tarryhill Road. Tarrytown, New York 10591. U.S.A. 361 the lower temperaturc. Conversely, if a gas saturated with water vapour is heated. it can hold more water. Its relative humidity falls. therefore. but its absolute humidity remains unchanged.

Climatic conditions occurring in nature are duplicated in the mini-environment of anaesthetic systems. Warm water vapour exhaled by the patient condenses in expiratory circuits. In systems which recycle anaesthetic gases. warm water vapour formed by the exothermic reaction of neutralization of soda lime by carbon dioxide partially condenses in the cooler external chan. nels after leaving the canister. The humidity of these gases is usually further reduced by admixture with the dry fresh gas supply from the anaesthetic machine.

\section{NECESSITY FOR HUMIDIFICATION OF anaesthetic Gases}

In 1962 Burton pointed out the injurious effects of dry anaesthetic gases.' He supported his allegation by clinical reports and animal studies. Earlier work by Toremalm ${ }^{2}$ had already shown that the administration of dry gases arrested the activity of the mucuciliary transport system. Marfatia, er al $^{3}$ later demonstrated extensive damage in the tracheabronchial tree of rabbits who had inhaled dry gases through a tracheal tube.

In 1967 Déry and coworkers studied the evolution of heat and moisture in the large carbon dioxide absorbers and noted that most of the initial moisture emitted by these soda lime containers was due to the water intentionally added to the alkali by the manufacturers. This water was used to form granules of ideal size to increase the absorbing surface to a maximum and to reduce formation of alkaline dust which. if inhaled. would burn respiratory mucous membranes. They also demonstrated that an increase in humidity and liberation of heat followed the exothermic reaction of neutralization of the lime by carbon dioxide. In a second paper written in the same year ${ }^{5}$ they studied the heat and moisture patterns in the respiratory tract of intubated pa- 
tients placed on semiclosed circle systems. Temperature rose from $32^{\circ} \mathrm{C}$ at the carina to $37^{\circ} \mathrm{C}$ at a depth of $20 \mathrm{~cm}$ within the bronchial tree, while humidity also increased. Rises in inspired humidity which followed rises in temperature were derived from the moisture of the lower respiratory tract. which acted as an artificial nose.

In 1971 Déry showed the alveolar humidity in the dog reached saturation at $37^{\circ} \mathrm{C} .{ }^{6}$ Two years later he calculated the water debt incurred by the trachea and bronchi of patients receiving general endatracheal anaesthesia through a nonrebreathing system. ${ }^{7} \mathrm{He}$ found that $20 \mathrm{~g}$ of water had to be added to the inspired stream each hour, of which $8.8 \mathrm{~g}$ came from the mechanical dead space and $11.8 \mathrm{~g}$ from the respiratory mucous membrane. In a paper published in the same year he found that the administration of gas mixtures saturated with water vapour at body temperature prevented loss of water from the respiratory tract and, therefore, reduced total body heat loss during surgery. ${ }^{8}$

In 1972 Chalon, et al.9 devised a method by which the damage to the ciliated cells of the tracheobronchial tree could be assessed by a point scoring system. They showed that dry gases administered through a tracheal tube for over an hour caused significant morphologic cellular changes. This correlated well with the water debt measurements of Déry. ${ }^{7}$ In a later extensive study of 202 patients ${ }^{10}$ they indicated that cellular damage increased exponentially as the humidity of inhaled gases was reduced. Using another point scoring system including physical examination, body temperature and roentgenology to quantitate the incidence and severity of postoperative pulmonary complications, they demonst rated that cellular damage was paralleled by a similar rise in respiratory morbidity.

As approximately 12 to 15 per cent of body heat is lost through the lung it stands to reason that the humidity of the inspired gases will affect body temperature during surgery. " As a rule, patients exhale gases saturated with a water vapour at $37^{\circ}$ C. Since they are poikilothermic under general anaesthesia, their temperature tends to rise or fall towards ambient, especially during intraabdominal operations when the peritoneum acts as an efficient heat and moisture exchanger. The to and fro system, which delivers warm moist gases, was considered responsible for the "heat stroke" and the so-called ether convulsions seen in a stress environment." Conversely, in cold operating rooms, the use of a high inspired humidity approximating saturated values at $32^{\circ}$ $C$, reduces heat loss during surgery and prevents shivering in the immediate postoperative period. ${ }^{12,13}$

\section{Sources of Humidity in Anaesthetic CIRCUITRY}

Anaesthetic gases available commercially are dried intentionally to prevent clogging of regulators and other valves. Therefore they actually reduce the amount of moisture available to the patient. The source of humidity in anaesthetic circuitry depends on a variety of factors which include: (1) water incorporated in lime granules for systems which eliminate carbon dioxide by chemical absorption, ${ }^{4}(2)$ the exothermic reaction of neutralization of the lime which emits water vapour. (3) warm moist gases exhaled by the patient into the circuitry, (4) water intentionally added into the system by the anaesthetist and (5) previous use of the circuit and ventilator, which return water of condensation accumulated during this previous use.

Many factors reduce the humidity output of the regular circle absorber system, which has a range of $5-18 \mathrm{mg} \mathrm{H}_{2}$ O/l (Table 1); a fact confirmed by Shanks and Sara, ${ }^{14}$ who found that the studies of Déry ${ }^{4}$ and Chalon ${ }^{28}$ yielded similar results. The designers of this circuit were concerned mainly with the efficient elimination of carbon dioxide and its humidity output was left to chance.

Factors which reduce the emission of water vapour include: (1) condensation of expired water vapour in the expiratory limb, (2) condensation of water from gases which leave the warm moist carbon dioxide absorption canister and enter conduits exposed to ambient temperature, (3) admixture of inspired gases with the fresh gas inflow, and (4) placement of the pressure release valve on the expiratory side, to economize on lime the reaction of neutralization, which is quantitative. emits less heat and water vapour).

Tube and bag systems such as the Mapleson D and its Bain modification have a higher humidity output than the regular circle (Table I). This is because patients placed on these circuits inhale and exhale through a common tube which acts as a heat and moisture exchanger. ${ }^{15}$ Their main drawback is that carbon dioxide, which is eliminated by the same route, may attain unacceptable inhaled concentrations when the fresh gas infiow used is too low, or when carbon dioxide production rises during surgery (light anaesthesia, hyperalimentation, endocrine aberrations, etc.). 
TABLE I

Humidity Output of Existing and Projected Anaesthetic Systems

\begin{tabular}{|c|c|c|c|c|c|c|}
\hline \multirow[b]{3}{*}{ Type of system } & \multicolumn{3}{|c|}{ Absolute humidity } & \multirow{3}{*}{$\begin{array}{l}\text { Period } \\
\text { of stabil- } \\
\text { ization } \\
\text { (minutes) }\end{array}$} & \multicolumn{2}{|c|}{$\begin{array}{l}\text { Factors affecting } \\
\text { humidity }\end{array}$} \\
\hline & \multirow{2}{*}{$\begin{array}{c}\mathrm{Wt} / \mathrm{V} \\
\mathrm{mg} \\
\mathrm{H}_{2} \mathrm{O} / 1\end{array}$} & \multicolumn{2}{|c|}{$\mathrm{PH}_{2} \mathrm{O}$} & & & \\
\hline & & torr & $\mathbf{k P a}$ & & $\mathrm{ml} / \mathrm{min}$ & $1 / \mathrm{min}$ \\
\hline \multicolumn{7}{|l|}{$\begin{array}{l}\text { In CURRent Use } \\
\text { Adult circle (regular) }\end{array}$} \\
\hline Semiclosed 28 & $5-18$ & $4-18$ & $0.53-2.4$ & 90 & $100-300$ & $2,5-10$ \\
\hline Closed $^{28}$ & 18 & 18 & 2.4 & 120 & 200 & 1 \\
\hline Bloomquist (reqular) ${ }^{29}$ & $0.5-11$ & $0.3-10$ & $0.04-1.34$ & 180 & $15-60$ & $1-5$ \\
\hline \multicolumn{7}{|l|}{ Bloomquist } \\
\hline (modified by Berry, et al. ${ }^{29}$ & $5-26$ & 4-27 & $0.53-3.6$ & 180 & $15-60$ & $1-5$ \\
\hline Columbia Pediatric 30 & $3-19$ & $2.5-19$ & $0.33-2.53$ & 120 & $15-60$ & $1-5$ \\
\hline $\begin{array}{l}\text { Mapleson D (Bain }{ }^{15} \text { modification) } \\
\text { Jackson-Rees }\end{array}$ & $13-20$ & $12.7-20$ & $1.7-2.66$ & 80 & 200 & 5 \\
\hline Spontaneous ventil. ${ }^{31}$ & 2.5 & 2 & 0.25 & 15 & 45 & 5 \\
\hline Controlled $^{31}$ & 8 & 7 & 0.93 & 15 & 45 & 5 \\
\hline \multicolumn{7}{|l|}{ New SySTEMS } \\
\hline Coaxial limbs on regular circle $e^{23}$ & $7-20$ & $6-20$ & $0.8-2.66$ & 60 & $100-300$ & 5 \\
\hline Vaporizer in lime 24 & $19-23$ & $19-24$ & $2.53-3.2$ & 210 & $100-300$ & 5 \\
\hline \multicolumn{7}{|l|}{ Coaxial limbs on ${ }^{12}$ New A bsorber } \\
\hline FGI in inspiratory limb 12 & $\begin{array}{r}28-29 \\
17\end{array}$ & 17.5 & 2.33 & 200 & 200 & 5 \\
\hline \multicolumn{7}{|l|}{$\begin{array}{l}\text { Vaporizer in lime in thew } \\
\text { canister }^{21}\end{array}$} \\
\hline FGl through vaporizer & $22-28$ & $22.3-29$ & $2.97-3.9$ & $90-180$ & $100-300$ & 5 \\
\hline FGI in lime after one hour & $28-29$ & $29-30$ & $3.86-4$ & 60 & 200 & 5 \\
\hline
\end{tabular}

Abbreviations: $F G I=$ fresh gas inflow, $W t / V=$ weight of water in $m g$ or $g$ per litre or cubic metre of gas.

humidification by Returning Condensed Water or AdDing Water to the Circuitry

Chamney 16 reviewed the many methods by which anaesthetic gases can be humidified. The simplest system, introduced by Chase, et al.., ${ }^{17}$ consists of wetting the corrugated tube of nonrebreathing systems. This will deliver an inspired humidity of 90 per cent at the beginning of anaesthesia. falling exponentially to 60 per cent after two hours. Some anaesthetists instill a few millilitres of water or physiological saline into the tracheal tube at regular intervals, but the efficiency of this method has not been established. Other anaesthetists introduce humidifiers into the circuit. These may be of three types: (1) passive humidifiers (also called heat and moisture exchangers), (2) vaporizers, and (3) nebulizers.

Heat and moisture exchangers, particularly the multiple metal gauze variety, will return approximately 60 per cent of exhaled humidity and are, therefore, useful adjuncts to circuits with a low humidity output. ${ }^{18}$ Vaporizers are instruments which emit water vapour by passing a current of gas over water or through it. They have to be heated either to maintain their efficiency or to raise their humidity output. The source of heat may be biological, electric or chemical. Nebulizers are instruments which emit water in the form of droplets and are of two types: the compressed gas and ultrasonic models. Droplets may contain solutes or particulate matter including bacteria. Their size is responsible for the depth to which they penetrate the respiratory tract or lung which, together with their number, will determine the amount of water delivered to the patient. Ambiavagar discovered an ingenious method by which the number and size of droplets delivered by nebulizers were assessed on a Bausch and Lomb calibrated light scatterer.* connected to a computer which directly printed out the required measurements. ${ }^{19}$ Tayyab, et al. used this instrument to measure the droplets delivered by a nonrebreathing system humidified by a Bird $500 \mathrm{ml}$ nebulizer. ${ }^{19}$ Droplets between I and 3 microns in diameter will reach bronchioles and are ideal in this respect. An inherent disadvantage associated with the use of nebulizers is that they may cause pulmonary infections if they are not effectively sterilized.

*Bausch and Lomb, Inc., Rochester. New York (Model 40-1). 


\section{Changis in ANAESTHETIC Circuitry Aimed} AT RAISING INHALED HUMIDITY

In order to avoid the use of electric heat to warm vaporizers. because of dangers associated with its use (burns, explusions and electrocutions) and nebulizers, whose humidity output is difficult to assess and which may cause hyperhydration and respiratory infections, anaesthetists have modified existing systems in an attempt to raise their moisture output without increasing inhaled carbon dioxide concentration.

Berry and Hughes-Davies ${ }^{20.21}$ have introduced the fresh gas inflow into the soda lime of both adult and paediatric circle systems. This has prevented the dilution of the moist inspiratory stream because the dry fresh gas inflow with which it mixes is now humidified during its passage through the lime. This manoeuvre. although effective, fails to prevent condensation of water in inspiratory conduits. Racz ${ }^{22}$ tried to minimize this aspect of the problem by surrounding the gas delivery tube of a humidified infant semi-open system with a second tube. He circulated water between these tubes with the pump and heating unit normally used to warm infant blankets. Ramanathan, ef $a^{2} .^{23}$ adapted coaxial inspiratory and expiratory limbs to a regular circle system. Within one hour, inspired humidity was raised 2 $\mathrm{mg} \mathrm{H}_{2} \mathrm{O} / \mathrm{l}$ above that of regular circles (Table I). ${ }^{23.24}$ Gases exhaled by the patient warmed the inner respiratory tube and droplets of vaporized water accumulated on the under surface of the leaflet of the inspiratory valve. which were then nebulized into the inspiratory limb during inspiration. Chalon, et al. ${ }^{2}$ used the coaxial tubes introduced by Ramanathan and mounted them on a modified circle system in which all external conduils had been introduced through the soda lime canister. The fresh gas inflow could be blown into the inspiratory limb or directly into the lime canister. Humidity delivered by this system varied from $171029 \mathrm{mg} \mathrm{H}_{2} \mathrm{O} / \mathrm{l}$ after a period of stabilization which lasted 90 minutes. Another method used by these authors included the use of a water vaporizer placed in the center of the lime canister and heated by the exothermic reaction of neutralization of the lime. It could be used both on adult circle systems ${ }^{24}$ and on semiopen paediatric circuits. ${ }^{25}$ The addition of coaxial tubes to the adult version raised inspired humidity still further ${ }^{26}$ (Table I). An infant version of the modified canister with coaxial tubing produced equally effective humidification ${ }^{27}$ (Table I). These humidity figures are respectively superior to those of the regular adult circle system. ${ }^{28}$ Bloomquist infant circuit ${ }^{24}$ (even when modified according to Berry, et al. ${ }^{20}$ ), Columbia paediatric circle system. ${ }^{30}$ and of the unhumidified Jackson Rees system "' (Table I).

\section{CONClustons}

A high inspired humidity offers many advantages which include the maintenance of body heat during anaesthesia, preservation of the activity of the mucociliary transport system and significant reduction in the incidence of postoperative pulmonary complications. Paediatic anaesthetists have been quick to recognize the usefulness of hemidified anaesthetic gases. This is because infant tracheal tubes are narrow and, therefore. prone to obstruction by dried mucous plugs in the absence of inhaled moisture. Moreover, since the surface/volume relationship of children is much larger than that of adults, their temperature fluctuates with ambient temperature faster than in older patients. This fact was shown by Rashad and Benson ${ }^{32}$ who introduced a special vaporizer for paediatric use. Anaesthetists who administer general endotracheal anaesthesia 10 adult patients seem less interested in humidity, despite the enormous number of papers published on the matter over the last four decades. Knudsen, of al. ${ }^{33}$ have claimed that humidification of anaesthetic gases did not reduce the incidence of pulmonary postoperative complications. This is contrary to our own experience. We used a larger series which was not limited to roentgenologic findings, as theirs was. We took great pains to estimate the physical condition of the chest of our patients accurately by examination. palpation. percussion and auscultation which, according to Hansen, $e t a l .^{34}$, is the most sensitive tool for the diagnosis of pulmonary morbidity. It is difficult. however, to dismiss their findings on these grounds alone. Patients vary tremendously in their biochemical, pathological and physical constitution. Studies conducted in different population groups may, therefore, produce different results. The reader should draw his own conclusions as to which study is likely to offer the best information. We have considered rises in remperature above $38.3^{\circ} \mathrm{C}\left(101^{\circ} \mathrm{F}\right)$ as indicative of minor degrees of pulmonary atelectasis which are invariably associated with the development of localized pneumonitis. We feel that humidification of anaesthetic gases is as important for adults as it is for children. We use it invariably in our practice. recognizing the increased risk of infec. 
tion caused by condensation of water in anaesthetic equipment and counteracting it by stringent sterilization or the use of disposable circuits. The growth of micro-organisms and. therefore, nosocomial infection by insufficiently sanitized apparatus even in the absence of added water has been the subject of numerous publications. ${ }^{35-42}$ We must also remember the dangers associated with humidification by electrically heated devices which include the possibility of overheating, explosions. and electrocutions. This is particularly applicable to the use of heated nebulizers which are electrically activated and also emit water droplets which may contain swarms of bacteria.

\section{RÉSUMÉ}

Les auteurs ont décrit les différentes définitions concernant l'humidité des gaz d'anesthésie et ont étudie les facteurs capables d'influencer sa régulation. Ils ont de plus demontré les effets néfastes de l'emploi des gaz secs qui déssèchent les muqueuses respiratoires et élèvent le pourcentage des complications pulmonaires qui suivent l'anesthésie. Une revue du débit de vapeur d'eau des systèmes en usage courant a été suivie par une description des mesures prises pour élever l'humidité des gaz respirés par les malades durant l'anesthésie. Ils ont aussi recommandé la réduction de l'humidité durant les périodes d'hyperthermie et les précautions à prendre pour éviter la contamination microbienne des equipements d'anesthésie. un risque augmenté durant l'hydratation des gaz aspirés par les malades.

\section{REFERENCES}

1. Burton, J.D.K. Effects of dry anaesthetic gases on the respiratory mucous membrane. Lance: I: 235 (1962).

2. TOREMALM, N.G. Airflow patterns and ciliary activity in the trachea after tracheostomy. Acta Oto-Laryngol. 53: 442 (1961).

3. Marfatia. S., Donahoe, P.K, \& Hendrin, W.H. Effect of dry and humidified gases on the respiratory epithelium in rabbits. 1 . Ped. Surg. 10: 583 (1975).

4. Déry, R., Pelletier, J., Jacques, A., et al. Humidity in anaesthesiology, II. Evolution of heat and moisture in the large carbon dioxide absorbers. Canad. Anaesth. Soc. J. 14: 205 (1967).

5. Déry. R.. Pelletier, J.. Jacques, A.. el al. Humidity in anaesthesiology. Heat and moisture patterns in the respiratory tract during anaesthesia with the semiclosed system. Canad. Anaesth. Soc. J. 14: 287 (1967).

6. DÉRY. R. Humidity in anaesthesiology, IV. Deter- mination of the alveolar humidity and temperature in the dog. Canad. Anaesth. Soc. J. 18: 145 (1971).

7. DÉRY, R. The evolution of heat and moisture in the respiratory tract during anaesthesia with a nonrebreathing system. Canad. Anaesth. Soc. J. 20: 296 (1973)

8. DÉRY, R. Water balance of the respiratory tract during ventilation with a gas mixture saturated at body temperature. Canad. Anaesth. Soc. J. 20: 719 (1973).

9. Chalon. J.. Loew, D.A.Y. \& Malebranche. J. Effect of dry anesthetic gases on tracheobronchial ciliated epithelium. Anesthesiology $37: 338$ (1972).

10. Chalon. J.. PATEl, C.. Alı. M.. el at. Humidity and the anesthetized patient. Anesthesiology (in press).

11. Clarke, R. E.. Orkin. L.R. \& Rovenstine. E.A. Body temperature studies in anesthetized man: effect of environmental temperature, humidity and anesthesia system. J.A.M.A. 154:311 (1954).

12. Chalon. J.. Patel. C. Ramanathan. S. el al. Humidification of the circle absorber system. Anesthesiology 48: 142 (1978).

13. Tausk, H.C., Miller, I, \& Roberts, R.B. Maintenance of body temperature by heated humidification. Anesth. Analg. 55: 719 (1976).

14. Sara, C.A. \& Shanks, C.A. Estimation of inspiratory limb humidity in the circle system. Anaesth. Int. Care 3: 41 (1974).

15. Ramanathan. S., Chalon, J., Capan, L.. et al. Rebreathing characteristics of the Bain anesthesin circuit. Anesth. Analg. 56: 822 (1977).

16. CHAMNEY, A.R: Humidification requitements and techniques. Anaesthesia 24:602 (1969).

17. Chase. M.. Trorta. R. \& Killmore. M.A. A simple method for humidifying nonrebrenthing anesthesia gas systems. Anesth. A nalg. 4I: 249 (1962).

18. Mapleson. W.W.. Morgan, J.G. \& Hill.ard. E.K. Assessment of condenser humidifiers with special reference to the multiple gauze model. Brit. Med. J. $l: 300$ (1963).

19. Tayrab. M.A., Ambiavagar, M. \& Chalon, J.: Water nebulization in a nonrebreathing system during anesthesia. Canad. Anaesth. Soc. J. 20: 728 (1973).

20. Berry, F.A. Jr.. Bal.l. C.G. \& Bl.Ankenbaker, W.l. Humidification of anesthetic systems for prolonged procedures. Anesth. Analg. 54: 50 (1975).

21. Berry, F. A. JR. \& Hughes-Davies, D.I. Methods for increasing the humidity and temperature of inspired gases in the infant circle system. Anesthesiology 37: 456 (1972).

22. RACZ, C.B. Humidification in a semiopen system for infant anesthesia. Anesth. Analg. 50: 995 (1971).

23. Ramanathan, S., Chalon, J. \& Turndorf, H. A compact well-humidified breathing circuit for the circle system. Anesthesiology $44: 238$ (1976).

24. Chalon, J. \& Ramanathan, S. Water vaporizer heated by the reaction of neutralization by carbon dioxide. Anesthesiology $4 /: 400$ (1974).

25. Chalon, J.. Simon, R., Patel, C.. et al. An infant circuit with a water vaporizer warmed by carbon dioxide neutralization. Anesth. Analg. 57: 307 (1978).

26. Chalon, J., Simon, R., Ramanathan, S. etal. A 
high humidity circle system for infants and children. Anesthesiology 49: 205 (1978)

27. Chalon, J., Goldman, C.. Amirdivani, M., er al. Humidification in a modified circle system. Anesth. Analg. (in press).

28. Chalon, J., Kao, Z.L.. Dolorico, V.N. \& ATKIN, D.H. Humidity output of the circle absorber system. Anesthesiology 38: 458 (1973).

29. Ramanathan, S., Chalon, J. \& Turndokf, H. Humidity output of the Bloomquist infant circle. Anesthesiology 43: 679 (1975).

30. Ramanathan, S.. Chalon, J. \& Turndorf, H. Humidity output of the Columbia pediatric circle. Anesth. Analg. 55: 877 (1976).

31. Ramanathan, S., Molse, A.D.. Chalon, J., et al. Direct estimation of arterial tension and metabolic production of carbon dioxide of children anesthetized on the Rees system. Anesthesiology (in press).

32. RASHAD, K.F, \& BENSON, D.W. Role of humidity in prevention of hypothermia in infants and children. Anesth. Analg. 46: 712 (1967).

33. KNUdSEN, J., LOMHOLT, N. \& WisBorg, K. Postoperative pulmonary complications using dry and humidified anaesthetic gases. Brit. J. Anaesth. 45: 636 (1973).
34. Hansen, G., Drablos, P.A. \& Steinert, R. Pulmonary complications, ventilation and blood gases after upper abdominal surgery. Acta Anaesth. Scand. $21: 211$ (1977)

35. JOSEPH, J.M. Disease transmission by insufficiently sanitized anesthesiology appatatus. J.A.M.A. 149: 1196(1952).

36. Ginzberg. F. Sterilizing anesthesia apparatus is difficult but necessary Mod. Hosp. 109: 108 (1952).

37. Gross, C.L. Decontamination of anesthesia apparatus. Anesthesiology 16:903 (1955).

38. Stark, D.C.C., Green, C.A. \& Pask, E.A. Anaesthetic machines and cross-infection. Anaesthesia 17: 12 (1962).

39. Pundit, S.K. Mehta, S. \& Agarwal, S.C. Risk of cross-infection from inhalation anaesthesia. Brit. J. Anaesth. 39: 839 (1967).

40. McNamara, M.J., Hill, M.C.. Ballows. A.. et al. A study of the bacteriologic patterns of hospital infections. Ann. Intern. Med. 66: 480 (1967).

41. Philips, I. \& Spencer. G. Pseudomonas aeruginosa cross-infection due to contaminated respiratory apparatus. Lancet 2: 1325 (1965)

42. DRYDEN, G.E. Risk of contamination from the anesthesia circle absorber: an evaluation. Anesth. Analg. 48: 939 (1969). 